\title{
Plasma soluble tumor necrosis factor- $\alpha$ receptors circulate in proportion to leptin levels during the menstrual cycle in lean but not in obese women
}

\author{
J M Fernández-Real, C Gutierrez ${ }^{1}$, J Vendrell ${ }^{1}$, R Casamitjana ${ }^{2}$ and W Ricart \\ Unitat de Diabetes, Endocrinología i Nutriciò, Hospital Universitario de Girona 'Dr Josep Trueta', Girona, Spain, ${ }^{1}$ Unitat d'Endocrinología i Nutriciò, \\ Hospital Universitario de Tarragona 'Joan XXIII', Tarragona, Spain and ${ }^{2}$ Servei de Laboratori Hormonal, Hospital Clínic, Barcelona, Spain \\ (Correspondence should be addressed to J M Fernández-Real, Unitat de Diabetes, Endocrinologia i Nutriciò, Hospital de Girona 'Dr Josep Trueta', \\ Ctra. França s/n, 17007 Girona, Spain; Email: endocrino@htrueta.scs.es)
}

\begin{abstract}
Objective: In recent studies serum leptin levels were significantly higher in the luteal phase than in the follicular phase, but the mechanism of changing leptin levels are unknown. Several research lines indicate a potential role for tumor necrosis factor (TNF- $\alpha$ ) in ovulation and reproductive events. As TNF- $\alpha$ appears to regulate leptin secretion, we speculated that TNF- $\alpha$ might be involved in leptin variations during the menstrual cycle.

Design and methods: Nine healthy never obese and ten overweight normally cycling women were studied. TNF- $\alpha$ action - through the plasma levels of the soluble fraction of the tumor necrosis factor receptors 1 and 2 (sTNFR 1 and sTNFR2) - and leptin concentrations were measured in the follicular (F), peri-ovulatory (PO) and luteal phases (L) of their menstrual cycles.

Results: Circulating leptin levels were significantly associated with the stage of the menstrual cycle $(P<0.001)$, being higher in PO and L phases. However, only three of ten overweight subjects vs eight of nine lean women (Chi square $P=0.014$ after Fisher's exact test) showed significantly higher leptin levels in the PO and L than in the F phase $(95 \%$ confidence interval $(95 \% \mathrm{CI})$ of the differences, 3.7 to $10.2 \mathrm{ng} / \mathrm{ml}$, paired $t$-test $P=0.001$ ). In these women (group 1 ), the changes in leptin levels parallelled the variations observed in plasma sTNFR1 $(2.50 \pm 0.1$ vs $2.11 \pm 0.05 \mathrm{ng} / \mathrm{ml}, P<0.0001,95 \% \mathrm{CI}$, 0.21 to 0.56$)$ and sTNFR2 levels $(5.19 \pm 0.28$ vs $4.55 \pm 0.25 \mathrm{ng} / \mathrm{ml}, P<0.0001,95 \% \mathrm{CI}, 0.47$ to 0.81 ). In the remaining women (group 2), leptin ( $95 \% \mathrm{CI},-1$ to $9.2 \mathrm{ng} / \mathrm{ml}, P=$ not significant (NS)), STNFR1 $(95 \% \mathrm{CI},-0.3$ to $0.14 \mathrm{ng} / \mathrm{ml}, P=\mathrm{NS})$ and sTNFR2 levels $(95 \% \mathrm{CI},-0.95$ to $0.39 \mathrm{ng} / \mathrm{ml}$, $P=\mathrm{NS})$ were essentially unaltered throughout the menstrual cycle. Group 2 women were similar in age $(36.1 \pm 2.9$ vs $37.3 \pm 1.4$ years) and significantly overweight (body mass index $31 \pm 2.9$ vs $23.9 \pm 1.2 \mathrm{~kg} / \mathrm{m}^{2}$ ) compared with group 1 women. A negative correlation was observed between leptin levels in the follicular phase and the change in plasma leptin from $\mathrm{F}$ to L phase in all subjects $(r=-0.67, P=0.002)$.

Conclusions: Circulating leptin and sTNFRs levels change significantly during the menstrual cycle of most lean women. In contrast, the levels of these molecules remain essentially unaltered during the F, PO and L phases in the majority of overweight women. Obesity might be associated not only with blunted diurnal excursions and dampened pulsatility, but also with blunted excursions during the menstrual cycle.
\end{abstract}

European Journal of Endocrinology 143 235-241

\section{Introduction}

There is increasing evidence that leptin is involved in reproductive events. It has been demonstrated that the administration of recombinant leptin restores full fertility in leptin-deficient female $(o b / o b)$ mice, one of the genetic models of obesity (1-3). Leptin stimulated luteinizing hormone (LH) production and increased primary and Graafian follicle numbers (2). Leptin also produced a dose-related increase in LH-releasing hormone, follicle-stimulating hormone (FSH) and LH release in in vitro and in vivo studies (4). In addition, the administration of leptin to normal prepubertal mice results in earlier maturation of the reproductive tract and earlier reproduction, despite the inhibition of growth rate (3). In humans, leptin levels were found to rise by approximately $50 \%$ just before the onset of puberty in boys (5). The onset of puberty has 
long been recognized to involve adipose tissue mass, once a critical body weight is reached (6-8). Menarche is thought to be triggered by the attainment of a critical percentage of fat, and the maintenance of menstrual cycles requires the persistence of a minimal level of fat $(7,8)$.

In recent studies serum leptin levels were found to be significantly higher in premenopausal than postmenopausal women (9), and higher in the luteal phase than in the follicular phase (9-12), with one exception (13), suggesting that estrogen regulates leptin production, although, a priori, progesterone cannot be excluded (10). Given that leptin changes were not related to changes in sex hormones (12), other factors should be investigated.

Several research lines indicate a potential role for tumor necrosis factor (TNF- $\alpha$ ) in ovulation (14-17) and in the molecular control of the implantation window (18). Immunoreactive TNF- $\alpha$ has been localized in the human granulosa cell layer of healthy antral follicles, in the ooplasm of the oocyte, and can be measured in human follicular fluid $(14,15)$. Granulosa cells collected from patients undergoing in vitro fertilization released TNF- $\alpha$ into the culture medium over a $15-\mathrm{h}$ incubation period (15). Furthermore, TNF- $\alpha$ has been consistently detected in uterine secretion in a recent study (19). TNF- $\alpha$ was found in quite low concentrations at the beginning of the cycle, rose sharply in the mid- to late proliferative phase and decreased towards the end of the cycle using immunohistochemistry, enzyme-linked immunosorbent analysis and reverse transcription-polymerase chain reaction (19).

TNF- $\alpha$ actions appear to occur via an autocrineparacrine mechanism. Circulating cytokine molecules are seldom found in the unbound state and are usually not informative. They are almost always bound to binding or carriers proteins, autoantibodies and soluble receptors. The usual sandwich-format immunoassays recover free and some predictably bound cytokine, but miss other cytokines bound by unpredictable binding entities. Neither the mechanisms that control this restricted activity nor the receptor systems that are involved in TNF- $\alpha$ signaling are clearly understood $(20,21)$. TNF signals through at least two known cell surface receptors (21) (tumor necrosis factor receptors; TNFRs): TNFR1 (p60) and TNFR2 (p80), that are present in virtually all cells of higher mammals. It appears that TNFR1 can signal for virtually all known activities of TNF, including apoptosis, differentiation, and proliferation. Both receptors for TNF exist also in soluble forms, apparently derived by proteolytic cleavage from the cell surface forms $(22,23)$. It has been suggested that soluble TNFR1 (sTNFR1) and sTNFR2 represent a buffer system that prolongs the biologic effects of TNF- $\alpha$ by forming a 'slow release reservoir' and impeding spontaneous denaturation of the cytokine (23). In this way, plasma sTNFRs might indicate a surrogate of previous TNF action because sTNFR1 and sTNFR2 levels remain elevated for longer periods of time after TNF administration (23).

TNF- $\alpha$ appears to regulate leptin secretion in vitro (24) and in vivo in mice (25), hamsters (26) and humans (27-30). Hence, we speculated that TNF- $\alpha$, if secreted into the plasma in parallel with ovary and uterine secretions, might be involved in leptin variations during the menstrual cycle. We therefore measured TNF- $\alpha$ action - through the levels of sTNFR1 and sTNFR2 - and leptin concentrations in follicular, peri-ovulatory and luteal phases in healthy women.

\section{Subjects and methods}

\section{Study population}

Nine never obese and ten obese normally cycling women (cycle length 27-32 days) were studied as healthy volunteers (staff from our hospital). All subjects were at their maximal lifetime weight and had maintained this weight within a $2 \mathrm{~kg}$ range for at least 3 months prior to enrollment. The early follicular phase blood extraction was performed within 3 or 4 days of the onset of menstrual bleeding. The mid-cycle and mid-luteal blood extractions were performed at days 12-15 and 17-22 respectively. A chart was given to all women to document their menstrual cycles.

Inclusion criteria included the following. (i) No consumption of drugs or alcohol $>20 \mathrm{~g}$ a day; (ii) absence of any systemic or metabolic disease other than obesity; (iii) no hormone use for 3 months, including oral contraceptive agents; (iv) absence of any infections in the previous month. None of the women had vasomotor symptoms or evidence of the perimenopause or of overt androgen excess (visible acne, abnormal facial hair or temporal hair recession). Appropiate informed consent was obtained prior to the study.

\section{Procedures}

Women with body mass index (BMI; (weight (kg))/ $\left.(\text { height }(\mathrm{m}))^{2}\right)>25 \mathrm{~kg} / \mathrm{m}^{2}$ were considered as overweight and subjects with BMI $<25 \mathrm{~kg} / \mathrm{m}^{2}$ were classified as lean.

Percentage of body fat and fat-free mass were measured using bioelectric impedance (Holtain, Cambridge, UK). The subject's waist was measured with a soft tape midway between the lowest rib and the iliac crest. The hip circumference was measured at the widest part of the gluteal region.

Each woman had three times of serum sampling across one cycle. Fasting glucose and insulin were measured only at the follicular phase.

\section{Laboratory analysis}

The serum insulin level was measured in duplicate by monoclonal immunoradiometric assay (Medgenix Diagnostics, Fleunes, Belgium). The lowest limit of detection was $4.0 \mathrm{mU} / \mathrm{l}$. The intra- and interassay coefficients of 
variation were $5.2 \%$ at a concentration of $10 \mathrm{mU} / \mathrm{l}$ and $6.9 \%$ at $14 \mathrm{mU} / \mathrm{l}$ respectively.

Immunoreactive serum leptin concentrations were measured in samples obtained after an overnight fast, between 0800 and $0830 \mathrm{~h}$ (Linco Research Inc., St Charles, MO, USA). The lower limit of detection was $0.5 \mathrm{ng} / \mathrm{ml}$. Intra- and interassay coefficients of variation were $<7 \%$ and $<8 \%$ respectively.

Plasma sTNFR1 and sTNFR2 levels were measured as previously described (30). In brief, the MEDGENIX sTNF-R1 and sTNF-R2 EASIA (BioSource Europe S.A., Fleunes, Belgium) are solid-phase enzyme amplified sensitivity immunoassays (EASIA) performed on microtiter plates. The minimum detectable concentration was estimated to be $0.1 \mathrm{ng} / \mathrm{ml}$ and was defined as the STNFR1 or sTNFR2 concentration corresponding to the average optical density of 20 replicates of the zero standard +2 standard deviations. The intra- and interassay coefficients of variation were $<7 \%$ and $<9 \%$. sTNFR1 EASIA does not cross-react with sTNFR2. TNF- $\alpha$ does not interfere with the assay.

LH and FSH were measured by immunoenzymatic assay with two monoclonal antibodies, one of them labeled with alkaline phosphatase (Technicon-Bayer, Tarrytown, NY, USA). Data are expressed in terms of the Second International Reference Preparation of Pituitary FSH (78/549) and the First International Standard for Pituitary LH (68/40). The sensitivity was $0.1 \mathrm{IU} / \mathrm{l}$ for $\mathrm{FSH}$ and $0.3 \mathrm{IU} / \mathrm{l}$ for $\mathrm{LH}$, with coefficients of variation of 2.7 and $3.3 \%$ respectively. Estradiol was determined by a competitive immunoenzymatic assay (Technicon-Bayer) with a detection limit of $10 \mathrm{pg} / \mathrm{ml}$ and a 5\% coefficient of variation. Progesterone was measured by a competitive immunoenzymatic assay (Immulite-DPC, Los Angeles, CA, USA). The sensitivity was $0.2 \mathrm{ng} / \mathrm{ml}$ and the coefficient of variation $6.7 \%$. The progesterone level was considered to be ovulatory if greater than $6 \mathrm{ng} / \mathrm{ml}$.

\section{Statistical analyses}

Descriptive results are presented as means \pm s.D. NonGaussian distributed variables were $\log _{10}$ transformed to achieve normality. This applied to leptin, estradiol, progesterone, sTNFR1 and sTNFR2. Relationships between variables were sought by Pearson's correlation coefficient, and between proportions by $\chi^{2}$ using Fisher's exact test. Comparison of variables across lean and obese women was performed by two-way ANOVA, with specific differences between stages of the menstrual cycle tested by the Bonferroni-Dunn post hoc test. Levels of statistical significance were set at $P<0.05$. All these analyses were performed with the BMDP statistical package (BMDP Statistical Software, Cork, Republic of Ireland).

\section{Results}

Table 1 summarizes the demographical and biochemical characteristics of the subjects. Three women in the lean group and two in the overweight group were current smokers. Any of the findings described below did not change substantially when these women were excluded from the analysis. Follicular leptin levels correlated with sTNFR1 in all subjects $(r=0.50$, $P=0.028)$, as recently demonstrated (28). When the menstrual cycle was subdivided into functional stages, circulating leptin levels were significantly associated with the stage of the menstrual cycle $(P<0.001)$, being higher in the peri-ovulatory and luteal phases. However, only three of ten obese subjects versus eight of nine lean women (Chi square $P=0.014$ after Fisher's exact test) showed significantly higher leptin levels in the midcycle and luteal phases than in the follicular phase (95\% confidence interval $(95 \% \mathrm{CI})$ of the differences, 3.7 to $10.2 \mathrm{ng} / \mathrm{ml}$, paired $t$-test $P=0.001$, Table 2 and Fig. 1). These changes in leptin levels parallelled the variations observed in plasma sTNFR1 $(2.50 \pm 0.1 \mathrm{vs}$ $2.11 \pm 0.05 \mathrm{ng} / \mathrm{ml}, P<0.0001,95 \% \mathrm{CI}, 0.21$ to 0.56$)$ and sTNFR2 levels $(5.19 \pm 0.28$ vs $4.55 \pm 0.25 \mathrm{ng} / \mathrm{ml}$, $P<0.0001$, 95\% CI, 0.47 to 0.81 ) (Fig. 2).

In the other women (group 2), both leptin (95\% CI, -1 to $9.2, P=$ not significant $(\mathrm{NS}))$, sTNFR $1 \quad(95 \%$ $\mathrm{CI},-0.3$ to $0.14, P=\mathrm{NS})$ and sTNFR2 levels $(95 \% \mathrm{CI}$, -0.95 to $0.39, P=\mathrm{NS}$ ) were essentially unaltered throughout the menstrual cycle (Table 2 and Fig. 1).

Table 1 Demographic and biochemical characteristics. Data are expressed as means \pm S.D.

\begin{tabular}{lccl}
\hline Variable & Lean women & Overweight women & $\boldsymbol{P}$ \\
\hline$n$ & 9 & 10 & \\
Age (years) & $35.8 \pm 2$ & $37.7 \pm 2.1$ & $\mathrm{NS}$ \\
BMl (kg/m $\left.{ }^{2}\right)$ & $24.2 \pm 1.7$ & $32.6 \pm 2.1$ & $<0.0001$ \\
Fat mass $(\mathrm{kg})$ & $7.6 \pm 1.6$ & $28 \pm 4.2$ & 0.001 \\
Fat-free mass $(\mathrm{kg})$ & $48.9 \pm 1.9$ & $56.7 \pm 2.3$ & 0.02 \\
Waist-to-hip ratio & $0.77 \pm 0.018$ & $0.79 \pm 0.013$ & $\mathrm{NS}$ \\
Fasting glucose (mmol/l) & $5.25 \pm 0.51$ & $5.52 \pm 0.62$ & $\mathrm{NS}$ \\
Fasting insulin (mU/l) & $7.4 \pm 1.1$ & $5.52 \pm 0.62$ & $\mathrm{NS}$ \\
Leptin (ng/ml) & $7.6 \pm 1$ & $28 \pm 6.3$ & 0.01 \\
\hline
\end{tabular}

NS, not significant. 
Table 2 Comparison between subjects with changing (Group 1) versus unaltered (Group 2) leptin levels. Data are expressed as means \pm S.D.

\begin{tabular}{lccl}
\hline Variable & Group 1 & Group 2 & $\boldsymbol{P}$ \\
\hline Lean/overweight & $8 / 3$ & $1 / 7$ & 0.014 \\
Age (years) & $37.3 \pm 1.4$ & $36.1 \pm 2.9$ & $\mathrm{NS}$ \\
BMl $\left(\mathrm{kg} / \mathrm{m}^{2}\right)$ & $23.9 \pm 1.2$ & $31 \pm 2.9$ & 0.025 \\
Fat mass $(\mathrm{kg})$ & $12 \pm 2.7$ & $26.9 \pm 6.2$ & 0.024 \\
Leptin ff $(\mathrm{ng} / \mathrm{ml})$ & $9 \pm 1.3$ & $31.3 \pm 7.4$ & 0.02 \\
Leptin max $(\mathrm{ng} / \mathrm{ml})$ & $15.9 \pm 2.5^{\star}$ & $35.3 \pm 8.5$ & 0.06 \\
Leptin $(\% \mathrm{change})$ & $81.5 \pm 15$ & $22 \pm 10.9$ & 0.009 \\
sTNFR1 $\mathrm{ff}(\mathrm{ng} / \mathrm{ml})$ & $2.11 \pm 0.1$ & $2.56 \pm 0.18$ & 0.045 \\
sTNFR1 max $(\mathrm{ng} / \mathrm{ml})$ & $2.5 \pm 0.05^{\star}$ & $2.47 \pm 0.20$ & $\mathrm{NS}$ \\
sTNFR1 $(\% \mathrm{change})$ & $18.4 \pm 3.6$ & $-3.8 \pm 3.4$ & 0.001 \\
sTNFR2 ff (ng/ml) & $4.55 \pm 0.25$ & $5.01 \pm 0.52$ & $\mathrm{NS}$ \\
sTNFR2 max (ng/ml) & $5.19 \pm 0.28^{\star}$ & $4.73 \pm 0.58$ & $\mathrm{NS}$ \\
sTNFR2 $(\% \mathrm{change})$ & $14.3 \pm 1.6$ & $-5.5 \pm 6.1$ & 0.01 \\
\hline
\end{tabular}

ff, follicular phase; max, maximal level reached in the mid-cycle and luteal phases. ${ }^{*} P<0.0001$ vs the same parameter in the follicular phase; NS, not significant.

The latter women were similar in age and significantly more obese (see Table 2). A negative correlation was observed between leptin levels in the follicular phase and the change in plasma leptin from follicular to luteal phase in all subjects $(r=-0.67, P=0.002)$.

Steroid hormones and gonadotropins exhibited characteristic secretion profiles throughout the menstrual cycle (Table 3 and Fig. 3). FSH, LH, and estradiol levels peaked at ovulation $(P<0.05)$ and subsided thereafter in all subjects. A peak in progesterone concentration $(P<0.05)$ occurred during the luteal phase of the cycle. There were no differences between group 1 and group 2 women in relation to these parameters (Table 3). LH in the peri-ovulatory phase was found to correlate with leptin in the peri-ovulatory and luteal phases $(r=0.67$ and $r=0.68, P=0.045$ and $P=0.042$ respectively) only in lean women. In contrast,

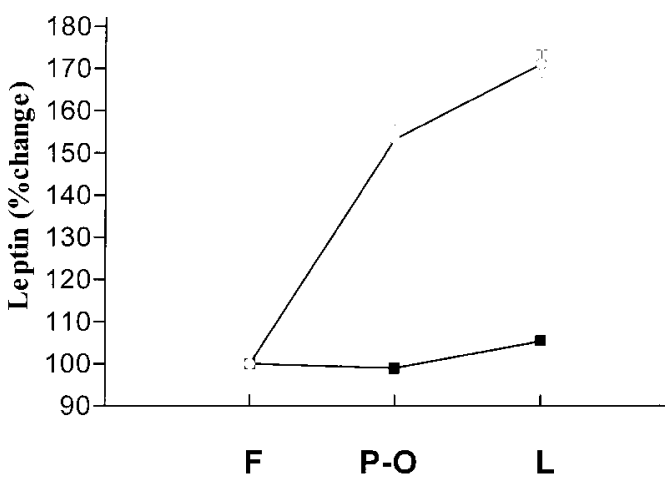

\section{Phase of the cycle}

Figure 1 Percentual change in serum leptin levels during the menstrual cycle in group $1(\bigcirc)$ and group $2(\boldsymbol{\square})$ subjects. The data are grouped according to the main stages of the ovarian cycle: F, follicular phase; $\mathrm{P}-\mathrm{O}$, peri-ovulatory period; L, luteal phase. leptin levels during the reproductive cycle were not found to correlate with either estradiol or progesterone.

\section{Discussion}

We here confirm recent findings concerning changes in plasma leptin during the menstrual cycle (9-12). However, these variations occurred mainly in lean women. In previous studies, leptin levels were found to change during the menstrual cycle in six women with a BMI of $21.6 \pm 0.5(10)$, in 15 women with a BMI of $22.9 \pm 3.1$ (11), in 13 women with a fat mass of $14.27 \pm 1.2 \mathrm{~kg}$ (similar to that in our group 1 subjects) (9), and in nine women with a BMI of $23.9 \pm 1.8$ (12). Only one study did not find changes in leptin during the menstrual cycle in eight women with a BMI of $21.2 \pm 1.6 \mathrm{~kg} / \mathrm{m}^{2}(13)$. We have observed leptin

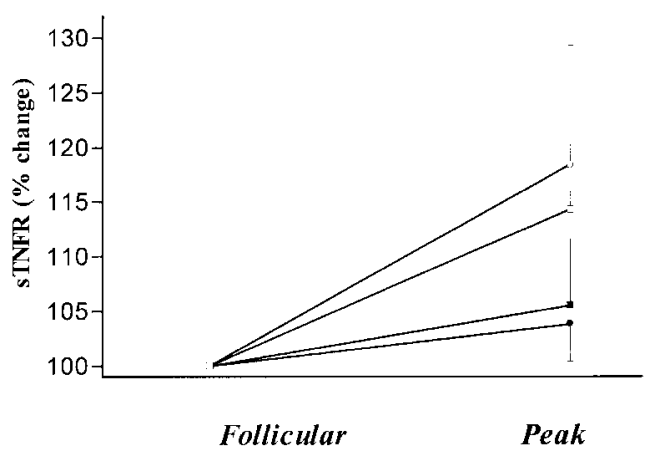

\section{Phase of the cycle}

Figure 2 Percentual change in plasma sTNFRs levels observed between the follicular phase and the maximal levels in the peri-ovulatory period or the luteal phase (Peak). Group 1 sTNFR1 $(\bigcirc)$, group 2 sTNFR1 $(\bullet)$, group 1 sTNFR2 $(\square)$ and group 2 sTNFR2 (ם). 
Table 3 Comparison between group 1 and group 2 subjects in gonadotropins and steroid hormones. Data are expressed as means \pm S.D.

\begin{tabular}{lccc}
\hline Variable & Group 1 & Group 2 & $\boldsymbol{P}$ \\
\hline LH ff $(\mathrm{IU} / \mathrm{l})$ & $7.3 \pm 1$ & $5.6 \pm 0.6$ & $\mathrm{NS}$ \\
LH max $(\mathrm{IU} / \mathrm{l})$ & $23.7 \pm 6.9 \dagger$ & $15.7 \pm 3.7 \dagger$ & $\mathrm{NS}$ \\
Estradiol $\mathrm{ff}(\mathrm{pg} / \mathrm{ml})$ & $57.7 \pm 18.4$ & $54.2 \pm 4.9$ & $\mathrm{NS}$ \\
Estradiol max $(\mathrm{pg} / \mathrm{ml})$ & $193.1 \pm 25^{\star}$ & $183.9 \pm 57.8 \dagger$ & $\mathrm{NS}$ \\
Progesterone $\mathrm{ff}(\mathrm{ng} / \mathrm{ml})$ & $0.65 \pm 0.07$ & $0.73 \pm 0.09$ & $\mathrm{NS}$ \\
Progesterone $\max (\mathrm{ng} / \mathrm{ml})$ & $9.18 \pm 1.3^{*}$ & $6.73 \pm 0.75^{\star}$ & $\mathrm{NS}$
\end{tabular}

ff, follicular phase; max, maximum level reached in the mid-cycle and luteal phases.

${ }^{*} P<0.01$ vs the same parameter in the follicular phase; $\uparrow P<0.05$ $v s$ the same parameter in the follicular phase; NS, not significant.

variations only in three out of ten overweight women. Although the circadian variation in leptin levels was controlled for, the pulsatile nature of leptin secretion was not in our study. However, recent studies involving more frequent sampling have demonstrated increases in plasma leptin in women with regular menstrual cycles and not in postmenopausal women (12). Furthermore, sTNFRs are quite stable proteins and their plasma concentrations changed significantly only in women in whom leptin had also changed.

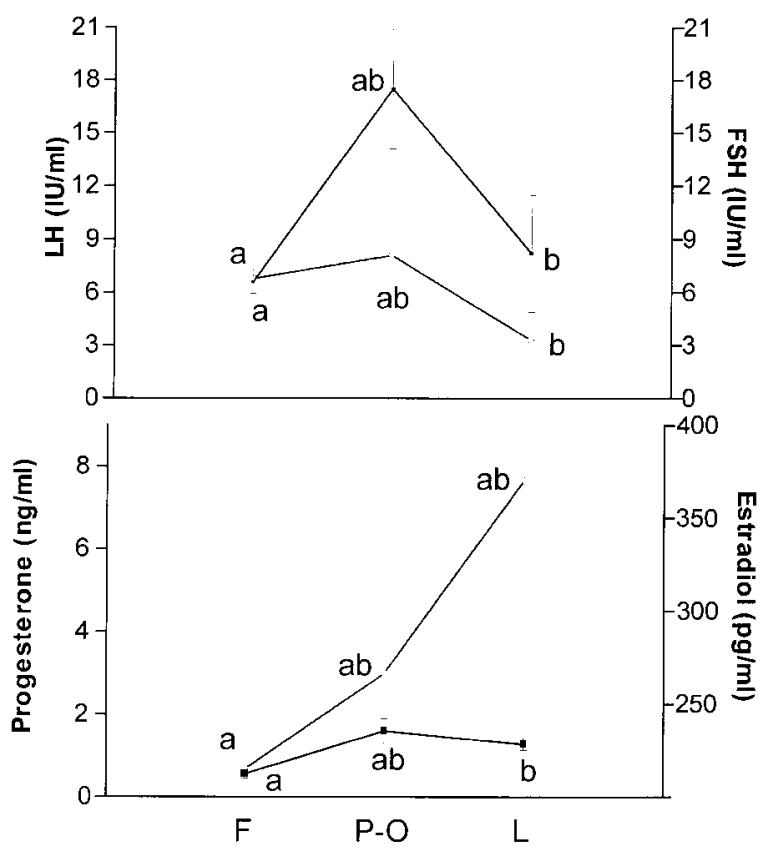

Phase of the cycle

Figure 3 Changes in circulating $\mathrm{LH}(\mathbf{\square})$, FSH $(\bigcirc)$ (top panel), estradiol (ם) and progesterone $(\bigcirc)$ (lower panel) in spontaneously cycling women. The data are grouped according to the main stages of the ovarian cycle: $\mathrm{F}$, follicular phase; P-O, peri-ovulatory period; L, luteal phase. Those points with the same initial are significantly different at $P<0.05$.
Obesity has been associated not only with higher leptin levels but also with blunted diurnal excursions and dampened pulsatility (31). In fact, a negative correlation between leptin levels in the follicular phase and their changes throughout the ovarian cycle $(r=-0.67, \quad P=0.002)$ was found, suggesting a flattened variability during the menstrual cycle. As abnormal rhythmicity has been hypothesized to contribute to leptin resistance in obesity (31), we speculate that the absence of significant changes in leptin levels during the menstrual cycle of overweight women might also contribute to their leptin resistance. Basal temperature levels are higher, metabolic rates are higher and caloric intakes are higher in the luteal phase of the normal menstrual cycle (32). Hence, increased leptin levels, as a reflection of leptin resistance, might have a role in preparing the body for the metabolic demands of pregnancy. Furthermore, in our experience, plasma levels of sTNFR 2 are associated with insulin resistance (30), and the latter is well described in the luteal phase of healthy women (33), just the phase in which sTNFR2 increased (this report).

Leptin regulates the minute-to-minute oscillations in the levels of $\mathrm{LH}$ and estradiol, and the nocturnal rise in leptin determines the change in the nocturnal LH profile in the mid-to-late follicular phase that precedes ovulation, as demonstrated in recent studies (34). That leptin influences ovary function had already been suggested by the finding of a high level of expression of the near identical receptor for the obesity gene product B219/ob-r in the human ovary and granulosa cells of the preovulatory follicle (35). The absence of significant oscillations in leptin concentrations during the menstrual cycle of obese women might be the cause of their increased prevalence of anovulatory cycles (36). In our overweight women, we have found unaltered levels of sTNFR1 and sTNFR2 coupled with flattened leptin concentrations during the ovarian cycle, which suggests that these cycles were anovulatory.

In agreement with Riad-Gabriel et al. (12) we found that changes in plasma leptin during the menstrual cycle were not related to changes in sex hormones. This means that additional factors might be involved. We provide here some data compatible with the idea that the increase in leptin is perhaps due to enhanced TNF- $\alpha$ action as a result of ovulation. As increased TNF- $\alpha$ concentration has been demonstrated to occur in uterine secretion in the mid-to-late proliferative phase (19), it is tempting to speculate that increased plasma sTNFR1 and sTNFR2 levels are reflecting the increased TNF- $\alpha$ action secreted into the plasma in parallel with its exogenous release. Gonadotropins have been found to induce the release of TNF- $\alpha$ from the human preovulatory follicle and, simultaneously, to correlate with circulating leptin during the menstrual cycle $(4,13$, present findings).

After the submission of this manuscript, another work has confirmed that leptin fluctuates during the 
menstrual cycle, increasing after a peri-ovulatory peak (37). In addition, endometrium from the proliferative phase has been found to express higher levels of TNF- $\alpha$ mRNA than that from secretory phase or during menses (38). Interestingly, TNFR1 expression was higher in endometrium from the secretory phase compared with the proliferative phase or with the menses (38), a finding that is extended with our observation of increased circulating sTNFRs in the luteal phase and its relation with leptin.

In summary, circulating leptin and sTNFRs levels change in parallel during the menstrual cycle of most lean women. In contrast, the levels of these molecules remain essentially unaltered during the follicular, periovulatory and luteal phases of overweight women. Whether leptin and sTNFRs oscillations are intercorrelated with ovulation rates merits further research.

\section{Acknowledgements}

We are grateful to A Pibernat and C Castillejo for technical assistance.

\section{References}

1 Chehab FF, Lim M \& Lu R. Correction of the sterility defect in homozygous obese female mice by treatment with the human recombinant leptin. Nature Genetics 199612 318-320.

2 Barash IA, Cheung CC, Weigle DS, Ren H, Kabigting EB, Kuijper JL et al. Leptin is a metabolic signal to the reproductive system. Endocrinology $19961373144-3147$.

3 Chehab FF, Mounzih K, Lu R \& Lim M. Early onset of reproductive function in normal female mice treated with leptin. Science 1997 $27588-90$.

4 Yu WH, Kimura M, Walczewska A, Karanth S \& McCann SM. Role of leptin in hypothalamic-pituitary function. Proceedings of the National Academy of Sciences of the USA $1997941023-1028$.

5 Mantzoros CS, Flier JS \& Rogol AD. A longitudinal assessment of hormonal and physical alterations during normal puberty in boys. V. Rising leptin levels may signal the onset of puberty. Journal of Clinical Endocrinology and Metabolism 199782 1066-1070.

6 Frisch RE. Body fat, puberty, and fertility. Biological Reviews of the Cambridge Philosophical Society 198459 161-188.

7 Frisch RE. Pubertal adipose tissue: is it necessary for normal sexual maturation? Federation Proceedings 198039 2395-2400.

8 Johnston FE, Malina RM, Galbraith MA, Frisch RE, Revelle R \& Cook S. Height, weight, and age at menarche and the 'critical weight' hypothesis. Science 1971174 1148-1149.

9 Shimizu H, Shimomura Y, Nakanishi Y, Futawatari T, Ohtani K, Sato $\mathrm{N}$ et al. Estrogen increases in vivo leptin production in rats and human subjects. Journal of Endocrinology 1997154 285-292.

10 Hardie L, Trayhurn P, Abramovich D \& Fowler P. Circulating leptin in women: a longitudinal study in the menstrual cycle and during pregnancy. Clinical Endocrinology 199747 101-106.

11 Lukaszuk K, Liss J, Kusiak E \& Wójcikowski Cz. Serum leptin concentrations increase during luteal phase in healthy premenopausal women. Hormone and Metabolic Research 199830 $172-173$.

12 Riad-Gabriel MG, Jinagouda SD, Sharma A, Boyadjian R \& Saad MF. Changes in plasma leptin during the menstrual cycle. European Journal of Endocrinology 1998139 528-531.

13 Teirmaa T, Luukkaa V, Rouru J, Koulu M \& Huupponen R. Correlation between circulating leptin and luteinizing hormone during the menstrual cycle in normal-weight women. European Journal of Endocrinology 1998139 190-194.

14 Roby KF, Weed J, Lyles R \& Terranova PF. Immunological evidence for human ovarian tumor necrosis factor- $\alpha$. Journal of Clinical Endocrinology and Metabolism 199071 1096-1102.

15 Zolti M, Meirom R, Shemesh M, Wollach D, Mashiach S, Shore L et al. Granulosa cells as a source and target organ for tumor necrosis factor- $\alpha$. FEBS Letters $1990261253-255$.

16 Brannström M, Norman RJ, Seamark RF \& Robertson SA. Rat ovary produces cytokines during ovulation. Biology of Reproduction $19945088-94$.

17 Brannström M, Bonello N, Wang LJ \& Norman RJ. Effects of tumour necrosis factor-alpha (TNF- $\alpha)$ on ovulation in the rat ovary. Reproduction, Fertility and Development 19957 67-73.

18 Tabibzadeh S. Molecular control of the implantation window. Human Reproduction Update 19984 465-471.

19 Von Wolff M, Classen-Linke I, Heid D, Krusche CA, BeierHellwig K, Karl C et al. Tumour necrosis factor-alpha (TNFalpha) in human endometrium and uterine secretion: an evaluation by immunohistochemistry, ELISA and semiquantitative RT-PCR. Molecular Human Reproduction 19995 146-152.

20 Tartaglia LA \& Goeddel DV. Two TNF receptors. Immunology Today $199213151-153$.

21 Smith CA, Farrah T \& Goodwin RG. The TNF receptor superfamily of cellular and viral proteins: activation, costimulation and death. Cell 199476 959-962.

22 Nophar Y, Kemper O, Brakebusch C, Engelmann H, Zwang R, Aderka D et al. Soluble forms of tumor necrosis factors (TNF-Rs). The cDNA for the type I TNF-R, cloned using amino acid sequence data of its soluble form, encodes both the cell surface and a soluble form of the receptor. EMBO Journal 19909 3269-3278.

23 Aderka D, Engelmann H, Maor Y, Brakebusch C \& Wallach D. Stabilization of the bioactivity of tumor necrosis factor by its soluble receptors. Journal of Experimental Medicine 1992175 323-329.

24 Kirchgessner TG, Teoman Uysal K, Wiesbrock SM, Marino MW \& Hotamisligil GS. Tumor necrosis factor- $\alpha$ contributes to obesity-related hyperleptinemia by regulating leptin release from adipocytes. Journal of Clinical Investigation 1997100 2777-2782.

25 Sarraf P, Frederich RC, Turner EM, Ma G, Jaskowiak NT, Rivet DJ III et al. Multiple cytokines and acute inflammation raise mouse leptin levels: Potential role in inflammatory anorexia. Journal of Experimental Medicine 1997185 171-175.

26 Grunfeld C, Zhao C, Fuller J, Pollock A, Moser A, Friedman J et al. Endotoxin and cytokines induce expression of leptin, the ob gene product, in hamsters. A role for leptin in the anorexia of infection. Journal of Clinical Investigation 199697 2152-2157.

27 Zumbach MS, Boehme MW, Wahl P, Stremmel W. Ziegler R \& Nawroth PP. Tumor necrosis factor increases serum leptin levels in humans. Journal of Clinical Endocrinology and Metabolism 1997 82 4080-4082.

28 Mantzoros CS, Moschos S, Avramopoulos I, Kaklamani V, Liolios A, Doulgerakis DE et al. Leptin concentrations in relation to body mass index and the tumor necrosis factor- $\alpha$ system in humans. Journal of Clinical Endocrinology and Metabolism 199782 3408-3413.

29 Fernández-Real JM, Gutierrez C, Ricart W, Casamitjana R, Fernández-Castañer $M$, Soler $J$ et al. The TNF- $\alpha$ Nco I polymorphism influences the relationship among insulin resistance, percent body fat and increased serum leptin levels. Diabetes 1997 46 1468-1472.

30 Fernández-Real JM, Broch M, Ricart W, Casamitjana, R, Gutierrez C, Vendrell J et al. Plasma levels of the soluble fraction of tumor necrosis factor receptor-2 and insulin resistance. Diabetes 199847 1757-1762.

31 Saad MF, Riad-Gabriel MG, Khan A, Sharma A, Michael R, Jinagouda SD et al. Diurnal and ultradian rhythmicity of plasma leptin: Effects of gender and adiposity. Journal of Clinical Endocrinology and Metabolism 199883 453-459. 
32 Barr SI, Janelle KC \& Prior JC. Energy intakes are higher during the luteal phase of ovulatory menstrual cycles. American Journa of Clinical Nutrition 199561 39-43.

33 Valdes CT \& Elkind-Hirsch KE. Intravenous glucose tolerance test-derived insulin sensitivity changes during the menstrual cycle. Journal of Clinical Endocrinology and Metabolism 199172 642-646.

34 Licinio J, Negroatildeño AB, Mantzoros C, Kaklamani V, Wong ML, Bongiorno PB et al. Synchronicity of frequently sampled, 24-h concentrations of circulating leptin, luteinizing hormone, and estradiol in healthy women. PNAS 199895 2541-2546.

35 Cioffi JA, Shafer AW, Zupancic TJ, Smith-Gbur J, Mikhail A, Platika D et al. Novel B219/ob recetor isoforms: Possible role of leptin in hematopoiesis and reproduction. Nature Medicine 19962 585589 .
36 Bray GA. Obesity and reproduction. Human Reproduction 199712 (Suppl 1) 26-32.

37 Cella F, Giordano G \& Cordera R. Serum leptin concentrations during the menstrual cycle in normal weight women: Effects of an oral triphasic estrogen-progestin medication. European Journal of Endocrinology $2000142174-178$.

38 Chegini N, Dou Q \& Williams RS. An inverse relation between the expression of tumor necrosis factor alpha (TNF-alpha) and TNF alpha receptor in human endometrium. American Journal of Reproductive Immunology 199942 297-302.

Received 2 September 1999

Accepted 5 April 2000 